\title{
WEB E-PROCUREMENT APPLICATION: USING TECHNOLOGY ACCEPTANCE MODEL TO SUPPLIER'S USE OF E-PROCUREMENT
}

\section{IN MALAYSIA}

\author{
Mohamed Fathi alaweti ${ }^{1}$, Nurdiana Azizan $^{2}$, Qaise Faryadi ${ }^{3}$
}

Faculty of since and Technology, University since Islamic Malaysia

Mralakrami@gmail.com¹, nurdiana@usim.edu.my², gaise@usim.edu.my ${ }^{3}$

\section{ABSTRACT}

This paper is research aim to extension of the technology acceptance model (TAM)to web E-procurement system. Focusing on suppliers and the E-procurement system impact on their organization performance, this paper has thus examined the factor that is connected with E-procurement system acceptance at supplier's organizations. A qualitative Data collected from 9 corporate suppliers from over 12 organizations helped with the Validation of the factors comprising perceived usefulness, perceived ease of use, supplier's involvement, reliability, security, vendor support and service provider support are identified and their underlying relationships are discussed in the light of the existing literature. Finally Intermediary results from a cluster analysis show differences among respondents that improve our understanding webbased procurement practice.

Key words: E-procurement, suppliers E-procurement adaption, TAM, usefulness, quality method.

\section{Council for Innovative Research}

Peer Review Research Publishing System

Journal: INTERNATIONAL JOURNAL OF COMPUTERS \& TECHNOLOGY

Vol 12, No. 10

editor@cirworld.com

www.cirworld.com, www.ijctonline.com 


\subsection{INTRODUCTION}

With the boom revolution of Internet technology, the electronic business transactions have become an obvious trend. The Electronic procurement (E-procurement) represents a significant piece of the global market and does justice to the investments made until now. The use of E-procurementwhich is web based procurement application could represent a big profit for the improvement of web based buying and selling services.Clifford and Alexandru(2012).

This phenomenon can be understood by the increase in the number of suppliers. Malaysia isstands out among one of the first developed countries that use this vehicle of dissemination of information and communication technology (ICT). Statistics show that the E-procurementin Malaysia has increased exponentially Mansor (2007). There was (6.1) billion transactions in the first half of 2008, compared to 2012 (9.09) billion, a growth of $45 \%$ in revenues from companies that trade through the Internet(Commercedotcome 2013).The development of an E-procurementsystem through new paradigms can affect several business areas of the companies that possibly want to adopt it (Md 2008).

This paper presents the issues related to supply chain management, E-procurement, barriers and facilitators to the adoption of E-procurement system. Proposes the following research methodology to study the problem, and this work will contribute to better address the problems faced by suppliers of E-procurement applications.

\subsection{LITERATURE REVIEW}

\subsection{Enablers for Supplier Adoption}

By understanding the main enablers that influence the supplier adoption of E-procurement, buyers can develop strategies to leverage the supplier adoption on an E-procurement implementation. The organization who is implementing an Eprocurementsolution should assess the impact of the system on suppliers and their technological promptness to implement the system at their end, and should provide the services necessary for the system to succeed. (Rajkumar 2001).

Suppliers need to gain conscience of the benefits resulting from their adoption of E-procurement. For suppliers, the adoption of E-procurementmay be an opportunity to expand their market. According to Sharifi, Kehoe \& Hopkins (2006) they will find E-procurement attractive because they could easily and cost effectively reaches new customers, improving their sales. (Berlak\& Weber, 2004). The integration between the buyer and the seller systems allows on-time delivery transactions and provides better service which can result in much more collaborative buyer-suppliersrelationships (Neef, 2001), CarayannisandPopescu (2005).

\subsection{Technology Acceptance Model (TAM)}

TAM is presented by Davis (1989) is an adaptation of the theory of Reasoned Action (TRA) specifically designed for modeling user acceptance of information systems. According Maniam and Halima (2009), TAM was developed to explain and predict the behavior of computer uses. Although many theoretical models have been proposed to describe the phenomenon of acceptance of information technology, states that the TAM beliefs influence attitudes, which led to the intentions and behaviors. Suggests TAM two installations for certain beliefs, which are regarded as interest (to what extent is expected to improve the performance of the adopter potential of technological innovation) is seen ease of use (the extent to which the adopter potential expected innovation technology to be free of effort in use) Background crucial to the process of technology adoption per capita (Maniam and Halima 2009).

\subsection{RESEARCH MODEL AND CONSTRUCT MEASUREMENTS}

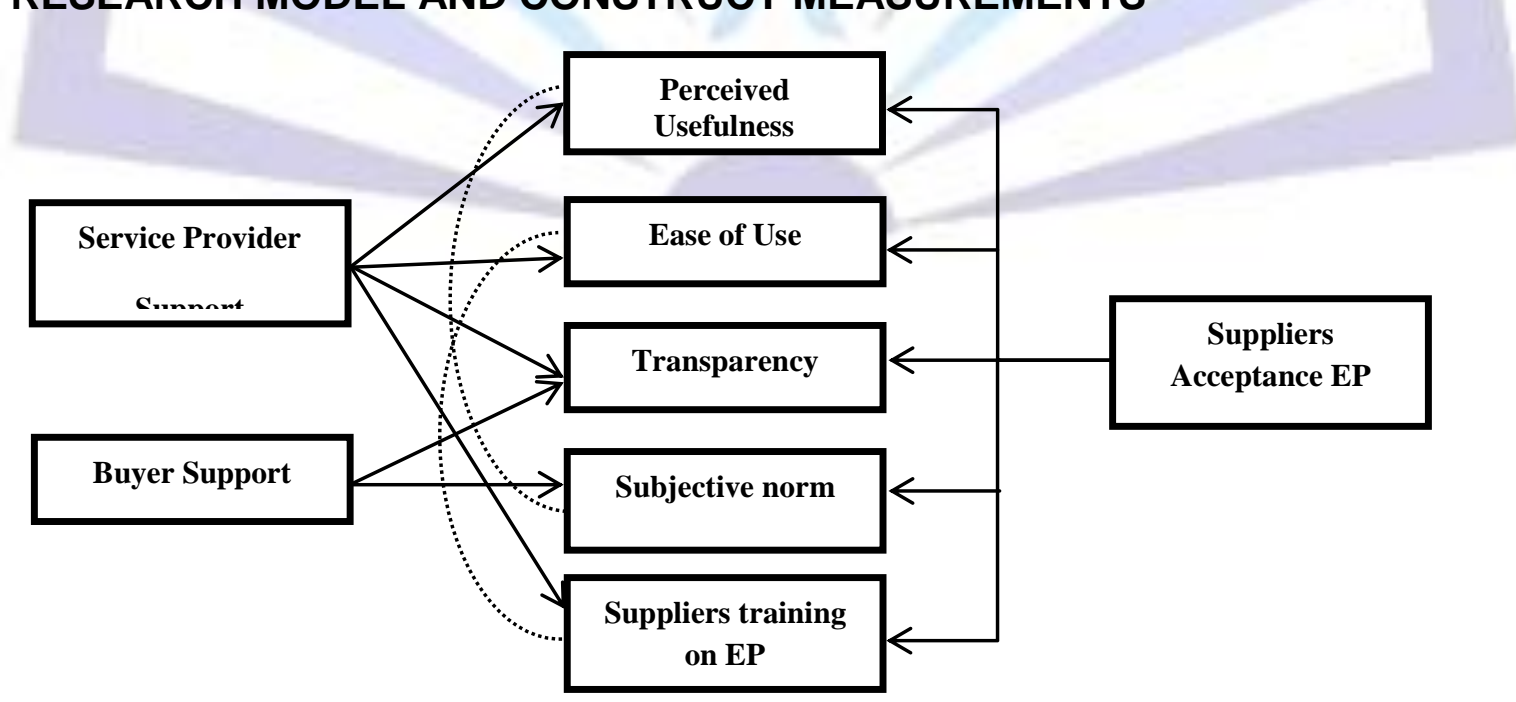

Figure 1 illustrate research model Modified based (Benslimane etal. 2004) 


\subsection{Service Provider Support (SPS)}

The most important service provider management barriers are: resistance to change, limited resources and problems in sharing information and collaboration with suppliers. Managers are afraid of changes that E-procurement will bring and they don't have the resources needed money, time, skilled personnel and breaking up post supplier relationships. Implementation of E-procurement does raise culture change issues and many organizations are not prepared for change for the adoption and implementation process (Kevin 2013).

\subsection{Perceived Usefulness (PU)}

Perceived usefulness refers to "the degree to which a person believes that using a particular systemwould enhance his or her job performance" (Davis 1989, p.320). Perceived usefulnessshould bepositively related to web systems usage. Perceived usefulness has a direct positive correlation with attitude towards using the system and behavior intention to use the system (Maniam 2010).

\subsection{Perceived Ease of Use (PEU)}

Perceived ease of use is "the degree to which a person believes that using a particular system would befree of effort" (Davis 1989, p.320). Perceived ease of use should also be completely related to E-procurementsystems players practice Segars and Grover (1993) as cited in Paulo(2009).

\subsection{Subjective Norm (SN)}

Subjective norm is defined in terms of social influences that lie at the heart of the diffusion process ofweb systems usage. Normative pressure favoring the use of E-procurement systems should too be positivelyrelated to actual use of such systems. Hartwick and Barki (1994) and Karahanna et al. (1999).

\subsection{Perceived Transparency (PT)}

The perceived lack of transparency refers to the uncertainty about the hazards of using E-procurement. From the supplier's perspective, this lack of transparency creates a potential for aloss and should therefore have a negative effect on E-procurement systems usage. Since no acceptable existingtransparency could be located, a new measure based on existing literature (Kosiur, 1997) there should be more trust relation between all E-procurement parties. Jarvenpaa etal. (1999).

\subsection{Perceived Suppliers Training (PST)}

The perceived lack of suppliers training is defined in terms of use the Internet-based systems efficiency and effectiveness on the job resulting more functioningto avoid unpredictable delay and downtime data packet loss (Metcalfe, 1997), (Baentsch et al., 1997;Zwass, 1996). The well trained suppliers are expected to have a positive effect on web Eprocurement systems usage and can help corporate buyers and service providers reduce their search costs, allowing them to carry out their tasks more quickly and/or to better select their suppliers. The measure was adapted from Goodhue (1998).

\subsection{METHODOLOGY}

The research methodology employed in this study was a qualitative research design with an illustration of a survey. Aqualitative research design uses interviews which are qualitatively describe the state of affairs as it exists at the present. A qualitative method was appropriate as the study involved fact finding to describe E-procurement on supply chain performance and document the findings.

\subsection{DATA COLLECTION}

Therefore, data collection for this research study was gathered using a qualitative study. This qualitative-based data describe central characteristics of selected organizations. Semi-structured interviews were conducted with 9 key suppliers organizations located in Malaysia. The major of using Semi-structured expert interviews and is that deals with real-life experiences. All interviews were face-to-face and lasted in excess of one hour. The choice of interviewees was based on a number of factors. These were; (i) perceived usefulness of E-procurement system, (ii) ease of use E-procurement system, (iii) transparency, (iv) subjective norms, and, (v) suppliers training in E-procurement system. The contact person in each organization was asked to indicate the most appropriate personnel to speak with regarding E-procurement, and all key personnel were interviewed in each organization. Those interviewed had both technical and general business backgrounds, and included representatives of both senior and middle level management.

\subsection{FINDINGS}

The result utilized an exploratory field study, interviewee were given an open, Axial and selective code. The coding scheme includes super categories, categories and subcategories and a data point is ascribed to the 'smallest' possible category. Every interviewee agreedthat the most issues of the factorsof E-procurement systems summarized in following steps.

\subsection{Service Provider and Buyer Supports.}

With the exception of Buyer, the service provider in collaborative relationship tends to stay with E-procurement suppliers. According to the interviewee, this not only affects the renewal phase of the E-procurement systems implemented by the service provider but also affects the entire system. The interviewers also reveal the service providers play role as 
"moderator" and service providers has an important role in stimulating the discussion. The moderator should be comfortable in the group, a trend that service providers utilizing adversarial relationships switch suppliers after the contract is fulfilled. This takes the service provider back to the information- gathering phase whereas suppliers organisations tend to iterate from the negotiation phase onwards.

\subsection{Perceived Usefulness}

The Usefulness aspect of the E-procurement system is further confirmed by a business executive (an active user of the system) interviewee has made the following remark: "TheE-procurement system provides us with an easy way of ordering goods and services from our desk without having to go out and get the information. It is simple and intuitive if thereis a strong relation with buyers and service provider it will be simplicity a major attraction for us." (Md2008).

\subsection{Perceived Ease of Use}

The some of the interviewee says E-procurement system isn't very easy. It's not intuitive. It was very hard for our people to learn how to use it in the first time, because the presence of the e-catalogue represents a selling power of the Eprocurement system. We explained to our employees how they can use the e-catalogue to promptly and correctly prepare the purchase orders. So, yes - we believe the e-catalogue gave them a convenient way of fulfilling their purchasing needs and it must be a simple, and we believe that E-procurement system if simplicity has accelerated it will acceptance from our users.

\subsection{Subjective Norm}

From the interviewee comments subjective norm means Complexity of current particular of E-procurement system which becomes the inhibitor that discourages the adoption of an innovation(Aboelmaged and Gebba 2013), our believes that using the E-procurement system must be free of mental effort and it must be concerned with the effort required to use that application and the complexity of the process E-procurement like token, fast response, usefulness, ease of use, transparency, suppliersinvolvement and suppliers training.

\subsection{Perceived Transparency}

The interviewers noticed, in an E-procurement system the tender documents were hosted in the E-procurement system for downloading free of cost from the day of publication of tenders. This has eliminated bidders' dependence on buyer's officials for issue of tender documents. Availability of information online to the suppliers has eliminated human interface with buyer's officials in pre- and post-tendering activities and this in fact has significantly contributed to reduce subjectivity and corruption in the procurement process. Information on the transactions, the committee of evaluation and award of contracts is automatically made available to the bidders on the E-procurement system. Transparency in the procurement processwill improved the buyer image and sharply will reduced instances of complain reports related to flaws in procurement processes.

\subsection{Perceived Suppliers Training}

To effectively communicate and more benefits of the E-procurement, according to the interviewees concept extensive training workshops must conduct for the suppliers, As mentioned workshops also served as good forums to receive supplier's feedback on the E-procurement system. This interviewee's feedback must always analysed and appropriate changes made in the process or the E-procurement system including even a small a thing as labeling a particular data field which is not familiar to the service provider can improve the E-procurement system.

\subsection{CONCLUSIONS}

From TAM perspective the supplier supporters of E-procurement will lead to better, more efficient,and more effective procurement management. Working from this belief,many state governments have implemented E-procurement initiatives toimprove their procurement management, some even attempting to pursuemarket integration through horizontal and vertical E-procurement.Relatively simple E-procurementfactors have diffused widely and rapidlyamong state governments in the past years, the primary objective of this research is to identify the factors that influence the behavioral intention of suppliers to use E-procurement system. This study was conducted to explore the factors influencing intention to use Eprocurement system tofactors determinants used which have positive effect on intension to use E-procurement system. In order to improve adoption level of suppliers, buyers and service provider's managers should develop some intervention programs to improve E-procurement system self-efficacy levels of the suppliers. They should also organize training programs and deploy advance IT infrastructure to support job performance and improve the quality of the supplier's work.

\section{REFERENCE}

[1] Aboelmaged. M, and Gebba. T., 2013 Mobile Banking Adoption: An Examination of Technology Acceptance Model and Theory of Planned Behavior.International Journal of Business Research and Development Vol. 2 No. 1.pp. 35-50 (2013).

[2] Baentsch, M., Baum, L. and Molter, G., 1997. Enhancing the Web's Infrastructure.IEEE Internet Computing, MarchApril, 18-27.

[3] Benslimane, Y., Plaisent, M., and Bernard, P., 2004.Using web systems for e- procurement: an extension of the unified theory of acceptance and use of technology, ECIS, 2004.

[4] Berlak, J., and Weber, V., 2004. How to make E-procurement viable for SME suppliers.Production Planning. 
[5] Carayannis, Elias G. and Popescu, D., 2005. Profiling a methodology for economic growth and convergence: learning from the EU E-procurement experience for central and eastern European countries. Technovation, Vol. 25.

[6] Clifford, M., and Alexandru V., 2012.E-procurement: myth or reality?Journal of public procurement, volume 12 .Issue 2. 212-238 summer 2012.

[7] Davis, F.D., 1989. Perceived Usefulness, Ease of Use and User Acceptance of IT. MIS Quarterly, 13, 3, 319-340.

[8] Goodhue, D.L., 1998. Development and Measurement Validity of Task-Technology Fit Instrument.

Hartwick, J. and Barki, H., 1994. Explaining the Role of User Participation in IS Use, Management Science, 40, 4, 440465.

[9] Jarvenpaa, S. L., and Tractinsky, N., 1999. Consumer Trust in an Internet Store. Journal of Computer Mediated Communication, 5, 2, 1-30.

[10] Karahanna, E., Straub, D.W. and Chervany, N.L., 1999. IT Adoption across Time. MIS Quarterly, 23, 2, $183-13$.

[11] Kevin, M., 2013,.determinants of electronic procurement on supply chain performance: a survey of tea factories in kisii county, nterdisciplinary, journal of contemporary research in business, VOL 4, NO 12 APRIL 2013.

[12] Kosiur, D., 1997. Understanding Electronic Commerce. Redmond: Microsoft Press.

[13] Maniam, K., Halimah, A., and Nurali, R., 2009, government purchasing: a review of E-procurement system in Malaysia, The Journal of Knowledge Economy \& Knowledge Management, Volume IV Spring 2009.

[14] Marc, R., Erik, M., and Sicco, C., 2004.Design of an E-procurement Adoption Model (EPAM).13th IPSERA conference.University of Catania. 2004.

[15] Md, M., 2008.Identifying Factors Affecting Acceptance of E-procurement Systems: An Initial Qualitative Study at an Australian City Council.Communications of the IBIMA Volume 3. 2008.

[16] Metcalfe, B., 1997. What's Wrong with the Internet.IEEE Internet Computing, March-April, 6-16.Mukopadhyay.

[17] Neef, D., 2001. E-procurement fromstrategy to implementation. USA: Prentice Hall.

[18] Paulo, A., and Bráulio, A., 2009.E-procurement adoption by suppliers: a research proposal. IADIS: International Conference e-Commerce 2009.

[19] Pedro, B., Sofiane, L., Rafael, S., and Rafael, S, S., 2009. IEBS: A MODEL FOR INTELLIGENT E-BIDDING. IADIS: International Conference e-Commerce 2009.

[20] Professor Norma Mansor., 2013. Public Procurement Innovation in Malaysia: E-procurement, Faculty of Economics and Administration University of Malaya. Kuala Lumpur.cited Feb 2014.

[21] Rajkumar, T. M., 2001. E-procurement: Business and Technical Issues. Information Systems Management, Vol. 18, No. 4 , pp. 52-60.

[22] Segars. A., and Grover, V., 1993. Re-Examining Perceived Ease of Use and Usefulness: A Confirmatory Factor Analysis. MIS Quarterly. Dec., 517-525.

[23] Sharifi, H., Kehoe, D. and Hopkins, J., 2006. A classification and selection model of e-marketplaces for better alignment of supply chains. Journal of Enterprise Information Management.Vol. 19.No. 5. pp. 483-503.

[24] Wan, S., Md, A., Dayang, H., 2011.Electronic Government Procurement Adoption Behavior amongst Malaysian SMEs.International Business Research. Vol. 4, No. 1; January 2011.

[25] Zwass, V., 1996. Electronic Commerce: Structure and Issues. International Journal of Electronic Commerce. 1. 1.323.

\section{Author biography}

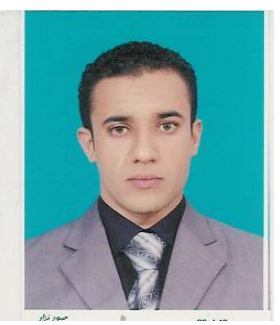

Mohamed Fathi Alaweti, PhD student in faculty of since and technology, university since Islamic Malaysia, Malaysia, area of study about E-government and precisely on electronic procurement and how to make the strong trust between the buyers and suppliers to make E-procurement more effective and more usable, also interested in networking and web designing. 